\title{
COMPARISON OF THE TOOTH SHAPE AND SIZE IN TABBY AND NON-TABBY MICE
}

\author{
P. ČERMÁKOVÁ ${ }^{1}$, M. PETERKA ${ }^{1}$, J. ĊAPKOVÁ ${ }^{2}$, J. TURECKKOVÁ ${ }^{1}$, J.V. RUCH ${ }^{3}$, \\ H. LESOT ${ }^{3}$, R. PETERKOVÁ ${ }^{1}$ \\ ${ }^{1}$ Department of Teratology, Institute of Experimental Medicine and \\ ${ }^{2}$ Institute of Molecular Genetics, Academy of Sciences of the Czech Republic. Prague, Czech Republic, \\ ${ }^{3}$ INSERM U-424, Faculté de Médecine, Strasbourg, France
}

Received January 12, 1998

Accepted March 3, 1998

\begin{abstract}
Cermáková P., M. Peterka, J. Ćapková, J. Turečková, J. V. Ruch, H. Lesot, R. Peterková: Comparison of the Tooth Shape and Size in Tabby and Non-tabby Mice. Acta vet. Brno 1998, 67: 3-14.

Basic anatomical and embryological investigations of the dental disorder in tabby mice were performed some 20-30 years ago. In order to bridge the gap in research activity in this field and as a prerequisite for future developmental studies, the dental characteristics of the tabby mice were updated in a stock presently available. Qualitative and quantitative parameters of the functional teeth were determined in 50 males and females of different phenotypes segregated from the stock of tabby mice. A parallel investigation was made in a common laboratory mouse (ICR stock). In ICR mice, the body weight was two times higher and this was reflected in the cheek teeth which were significantly larger (but similar in shape) when compared to the wild type non-tabby controls. Among tabby homozygous and hemizygous mice, at least one incisor was absent in 50\% of females, and in $70 \%$ of males - where predominance of the right side was apparent. In these groups the mean length and width of the cheek teeth were significantly reduced compared to the corresponding wild type controls, despite similar body weight. Changes in crown pattern, including also reduction or absence of cusps, resulted in characteristic morphology of the cheek teeth. In contrast to the earlier literature, duplication of an incisor or an explicit supernumerary tooth in the cheek region were not found in the present tabby collection and the heterozygous specimens were less affected.
\end{abstract}

Gene, mutation, syndrome, anomaly, development

Congenital decreases or increases in tooth number (hypodontia, hyperodontia) and size (microdontia, macrodontia) are well recognised clinical features in dental pathology. The most frequent disturbance is hypodontia, which is more common in humans than in other species. It affects about $7 \%$ of the human population (exclusive of agenesis of the third molars, which occurs in 10-25\% of population), (Jorgenson 1980). In patients with orofacial clefts, congenital tooth agenesis increases to 10-40\% (Pöyry and Ranta 1985). Hypodontia may be associated with microdontia. Hyperodontia and macrodontia are much less frequent (Ravn 1971).

Dental anomalies have been reported in more than 25 genetic syndromes exhibiting autosomal dominant, autosomal recessive or $\mathrm{X}$-linked heredity. The dentition is severely affected in ectodermal dysplasias. The classic variety - hypohidrotic (anhidrotic) ectodermal dysplasia includes hypodontia (or even anodontia); the existing teeth exhibit smaller size and modified shape (Salmon and Lindenbaum 1978; Jorgenson 1980; Craw ford et al. 1991). The hypohidrotic ectodermal dysplasia is considered to be homologous to the 
mouse X-linked tabby (Ta) syndrome (Weeks 1983; Blecher 1986). In comparison with non-mutant mice, Ta carriers exhibit characteristic defects of hair, exocrine glands, and teeth (Grüneberg 1971; Green 1981a). The incisors may be hypoplastic, fused or absent, the third molar may be absent and the first and second molars are reduced in size and their shape is simplified. A supernumerary tooth may be present in front of the upper or lower molars. Macrodontia of the first molar may occur (Grüneberg 1965, 1966; S of a er 1969ab, 1979; Miller 1978). Disturbance of the epithelio-mesenchymal interactions in the tabby mouse has been suggested to explain the developmental defects of various epithelial derivatives including the dentition (Miller 1978). The tabby mouse, therefore, represents a valuable model to analyse some of the mechanisms involved in abnormal development of teeth and of other epithelial-derived structures.

Basic postnatal and prenatal investigations on the tabby teeth were performed some 20-30 years ago by Grüneberg $(1965,1966)$, Sofaer $(1969 \mathrm{ab}, 1975,1979)$ and Miller (1978). As a prerequisite for future developmental studies focusing on the aetiopathogenesis of tooth defects in tabby mice, the characteristics of their postnatal dentition were determined in a tabby stock available commercially at present. Qualitative and quantitative tooth parameters were determined and compared in various phenotypes segregated from a stock of the tabby mouse. These results were confronted with findings of a parallel study in the common laboratory mouse (ICR stock) and with earlier literature on the pattern of tabby teeth. This knowledge will provide essential background for the design, completion and interpretation of future tooth developmental studies in the tabby mutants.

\section{Materials and Methods}

Mice

Three groups of mice were investigated: tabby mutant males and females, their non-tabby (wild-type) counterparts and ICR mice (Table 1-4). The tabby phenotypes of the mice were determined according to external anatomical criteria (Green 1981a).

\section{Tabby mutant mice}

The animals were segregated from the inbred tabby line B6CBACa-AW-J/A-Ta/0 (the breeder pairs were purchased from the Jackson Laboratory, U.S.A):

$(\mathrm{Ta} / \mathrm{Ta})$ homozygous females $\mathrm{X} / \mathrm{X}$

$(\mathrm{Ta} /+)$ heterozygous females $\mathrm{X} / \mathrm{X}$

$(\mathrm{Ta} / 0)$ hemizygous females $\mathrm{X} / \mathrm{O}$

$(\mathrm{Ta} / 0)$ hemizygous males $\mathrm{X} / \mathrm{Y}$

These animals were successors of inbred crossings between tabby females $(\mathrm{Ta} / \mathrm{Ta}, \mathrm{Ta} / 0$, or $\mathrm{Ta} /+)$ with tabby $(\mathrm{Ta} / 0)$ or wild type $(+/ 0)$ males. The Ta-homozygous females and Ta-hemizygous males and females exhibited an identical phenotype (except for reproductive organs). For this reason the $\mathrm{Ta} / \mathrm{Ta}$ and $\mathrm{Ta} / 0$ females were joined in a unit group indicated as Ta-homozygous/hemizygous females.

\section{Control non-mutant mice}

Control mice were generated by inbreeding of wild-type (phenotypically normal, non-tabby) brothers and sisters of mutant animals. The male and female successors were harvested as representatives of the genetic background for Ta allele:

$(+/+)$ homozygous female $\mathrm{X} / \mathrm{X}$

$(+/ 0)$ hemizygous female $\mathrm{X} / \mathrm{O}$

$(+/ 0)$ hemizygous male $\mathrm{X} / \mathrm{Y}$

All these animals exhibited a normal, non-tabby phenotype and are indicated as wild-type (WT) males or females in the text. The females $(+/+)$ and $(+/ 0)$, that could not be distinguished anatomically from external features, were combined in a unit group of WT females.

\section{ICR mice}

The specimens were obtained from random-bred crossings between the ICR (Velaz, C.R.) males and females. 
Material preparation

Ten animals from each genotype/phenotype subgroup (Table 1-4) were collected from 1995 till 1997. Only one male and/or female of a given phenotype was harvested from each litter during postnatal days 24-26 (day of birth $=$ day 0 ). At that time, functional occlusion of the first and second molars should have been achieved (Cohn 1957). The specimens were killed by ether inhalation and weighed. Where necessary, the identification of males or females was confirmed by dissection of internal genital organs. The heads of animals were fixed in $96 \%$ ethanol and the lower jaw isolated by careful dissection under a stereo-loupe (Zeiss). The upper and lower teeth were counter-stained with hematoxylin.

\section{Morphological evaluation}

Identification of the cheek teeth as the first (MI), second (M2) and third (M3) molar, and evaluation of their cusp pattern (Plate I., Fig.1A, Plate II., Fig. 1D) were made according to morphological criteria (Gaunt 1955). Where alteration of crown shape prevented explicit identification, the cheek teeth were identified as the first, second and third tooth in the mesio-distal sequence (Plate II., Fig. 1F).

Variable features of Ml (Grüneberg 1965; Sofaer 1969c) were also taken into account: the small cusp near the base of cusp 1, the extra cusp or a ridge between $\mathrm{B} 2$ and $\mathrm{B} 3$ cusps (Plate III., Fig. 1G.H), and the mutual relationship between cusps B3 and 3 (separation or fusion of their enamel free areas) in the upper first molar (Grüneberg 1965), as well as the small extra cusp between BI and LI (Plate II., Fig. 1D) in the lower first molar (Sof aer 1969c).

In the second upper molar, the presence of a ,rampart" (formed by the cusps Bl and Ll interconnected by a transversal ridge - Grün e be rg 1966) was investigated (Plate I., Fig. 1A,C).

\section{Morphometry}

The crown size of the cheek teeth (Tab. 1-4, Fig. 2 and 3) was measured using a stereo-loupe equipped with an ocular micrometer at $42 x$ magnification. The maximum mesio-distal length and the maximum buccolingual width were measured in each crown parallel to the occlusal plane. In addition, the maximum total length was determined for $\mathrm{M} 1+\mathrm{M} 2$ (tooth $1+2$ ). For information (without further statistical processing), third molars were measured in which the largest part of the crown had already emerged into the oral cavity (Table 1-4). All measurements were standardised and the subjective error of measurement was determined to be nonsignificant.
Table 1

Mean length and width of the cheek teeth in maxilla and mandible of ICR males and females

\begin{tabular}{|c|c|c|c|c|c|c|c|c|}
\hline \multirow{2}{*}{\multicolumn{2}{|c|}{${ }^{\circ} 0^{\circ}$ ICR }} & \multicolumn{4}{|c|}{ length $(\mathrm{mm})$} & \multicolumn{3}{|c|}{ width $(\mathrm{mm})$} \\
\hline & & \multirow{2}{*}{$\frac{1+2}{3.02}$} & 1 & \multirow{2}{*}{$\frac{2}{1.21}$} & \multirow{2}{*}{$\begin{array}{r}3 \\
0.69\end{array}$} & \multirow{2}{*}{$\frac{1}{1.17}$} & \multirow{2}{*}{$\frac{2}{1.00}$} & \multirow{2}{*}{$\begin{array}{r}3 \\
0.68 \\
\end{array}$} \\
\hline $\mathrm{mx} \mathrm{L}$ & Mean & & 1.99 & & & & & \\
\hline & $\mathrm{SD}$ & 0.08 & 0.05 & 0.05 & 0.03 & 0.03 & 0.03 & 0.02 \\
\hline & Number & 10 & 10 & 10 & 7 & 10 & 10 & 7 \\
\hline \multirow[t]{3}{*}{$\mathrm{mx} \mathrm{R}$} & Mean & 3.05 & 2.00 & 1.21 & 0.70 & 1.16 & 1.01 & 0.68 \\
\hline & SD & 0.07 & 0.06 & 0.05 & 0.04 & 0.03 & 0.03 & 0.02 \\
\hline & Number & 10 & 10 & 10 & 7 & 10 & 10 & 7 \\
\hline \multirow[t]{3}{*}{$\mathrm{mb} \mathrm{L}$} & Mean & 2.59 & 1.58 & 1.02 & - & 0.96 & 0.95 & - \\
\hline & SD & 0.07 & 0.04 & 0.04 & - & 0.03 & 0.02 & - \\
\hline & Number & 10 & 10 & 10 & 0 & 10 & 10 & 0 \\
\hline \multirow[t]{3}{*}{$\mathrm{mb} R$} & Mean & 2.59 & 1.59 & 1.03 & - & 0.97 & 0.97 & - \\
\hline & SD & 0.07 & 0.04 & 0.04 & - & 0.03 & 0.03 & - \\
\hline & Number & 10 & 10 & 10 & 0 & 10 & 10 & 0 \\
\hline
\end{tabular}

\begin{tabular}{|c|c|c|c|c|c|c|c|c|}
\hline \multirow{2}{*}{\multicolumn{2}{|c|}{ $९$ ICR }} & \multicolumn{4}{|c|}{ length $(\mathrm{mm})$} & \multicolumn{3}{|c|}{ width $(\mathrm{mm})$} \\
\hline & & \multirow{2}{*}{$\frac{1+2}{2.95}$} & \multirow{2}{*}{$\frac{1}{1.95}$} & \multirow{2}{*}{$\frac{2}{1.17}$} & \multirow{2}{*}{$\frac{3}{0.71}$} & \multirow{2}{*}{$\frac{1}{1.17}$} & \multirow{2}{*}{$\frac{2}{1.00}$} & \multirow{2}{*}{$\frac{3}{0.68}$} \\
\hline$m x L$ & Mean & & & & & & & \\
\hline & SD & 0.08 & 0.07 & 0.04 & 0.06 & 0.04 & 0.04 & 0.04 \\
\hline & Number & 10 & 10 & 10 & 8 & 10 & 10 & 8 \\
\hline \multirow[t]{3}{*}{$\mathrm{mxR}$} & Mean & 2.98 & 1.97 & 1.19 & 0.71 & 1.14 & 1.00 & 0.67 \\
\hline & SD & 0.07 & 0.05 & 0.04 & 0.06 & 0.03 & 0.02 & 0.02 \\
\hline & Number & 10 & 10 & 10 & 8 & 10 & 10 & 8 \\
\hline \multirow[t]{3}{*}{$\mathrm{mb} \mathrm{L}$} & Mean & 2.54 & 1.57 & 1.02 & 0.61 & 0.97 & 0.96 & 0.67 \\
\hline & SD & 0.05 & 0.02 & 0.04 & 0.02 & 0.03 & 0.03 & 0.03 \\
\hline & Number & 10 & 10 & 10 & 3 & 10 & 10 & 3 \\
\hline \multirow[t]{3}{*}{$\mathrm{mb} R$} & Mean & 2.54 & 1.56 & 1.01 & 0.57 & 0.98 & 0.96 & 0.63 \\
\hline & SD & 0.04 & 0.03 & 0.04 & 0.05 & 0.03 & 0.03 & 0.04 \\
\hline & Number & 10 & 10 & 10 & 3 & 10 & 10 & 3 \\
\hline
\end{tabular}

$\mathrm{mm}$ - millimeters, SD - standard deviation, $\mathrm{mx}$ - maxilla, $\mathrm{md}$ - mandible, $\mathrm{L}$ - left side, $\mathrm{R}$ - right side, $\delta^{0} \delta^{0}-$ males. $\$+q-$ females.

$1,2,3$ - the first, second and third molar, respectively. 
Statistics

The results were compared between the right and left contralateral dental quadrants in each subgroup of males or females of an identical phenotype using the $\mathrm{t}$ test (paired two sample for means). Except for specific cases, where a significant right/left difference was found, the right and left values were combined in one sample group for further testing: Sex differences in tooth size were evaluated between males and females of identical phenotype by means of the two sample t-test. This test was also applied to comparison of the tooth size between different subgroups of mice and for evaluation of differences in body weight. The t-test was also employed to test any eventual influence of mother phenotype (Ta-heterozygous or Tahomozygous/hemizygous) on tooth size in their Tahomozygous/hemizygous

daughters. The statistical significance was determined with respect to the usual limits $\mathrm{P}<0.05$ and $\mathrm{P}<0.01$.

\section{Results}

\section{Incisors}

In both ICR and Taheterozygous mice, all incisors were present, well formed and in correct occlusion. Among WT mice, an inclination was observed for one or both contra-lateral incisors in the upper jaw of $10 \%$ of males and $20 \%$ of females. In the latter group, an associated inclination of the lower incisors was also apparent.

An incisor was absent in 70\% of Ta-hemizygous males: The right lower and upper incisor was absent in $40 \%$ and $30 \%$ of animals, respectively. On the left side. the incisor was missing in 10\% of upper or lower jaws. In Ta-homozygous/hemizygous females, the lower incisor was absent in $30 \%$ of right and in $20 \%$ of left quadrants, and the upper one was absent in $10 \%$ of left quadrants. Both upper or lower contra-lateral incisors were absent in $10 \%$ of males or females, respectively.

Absence of an incisor was associated both with malocclusion and with inclination of the remaining teeth in the incisor region; in some cases, the incisor exhibited a smaller diameter (not evaluated quantitatively).
Table 2 width of the cheek teeth in maxilla
WT (wild type) males and females

\begin{tabular}{|c|c|c|c|c|c|c|c|c|}
\hline \multirow{2}{*}{\multicolumn{2}{|c|}{$\delta \delta \mathrm{WT}(+/ 0)$}} & \multicolumn{4}{|c|}{ length $(\mathrm{mm})$} & \multicolumn{3}{|c|}{ width (mm) } \\
\hline & & \multirow{2}{*}{$\frac{1+2}{2.68}$} & 1 & \multicolumn{2}{|l|}{2} & \multirow{2}{*}{$\frac{1}{1.13}$} & \multirow{2}{*}{$\frac{2}{98}$} & \multirow{2}{*}{$\frac{3}{0.64}$} \\
\hline $\mathrm{mx} \mathrm{L}$ & Mean & & 1.76 & 1.11 & 0.65 & & & \\
\hline & SD & 0.06 & 0.04 & 0.04 & 0.01 & 0.04 & 0.04 & 0.04 \\
\hline & Number & 10 & 10 & 10 & 4 & 10 & 10 & 4 \\
\hline \multirow[t]{3}{*}{$\mathrm{mx} R$} & Mean & 2.68 & 1.78 & 1.12 & 0.66 & 1.10 & 0.99 & 0.65 \\
\hline & SD & 0.06 & 0.04 & 0.05 & 0.02 & 0.03 & 0.04 & 0.06 \\
\hline & Number & 10 & 10 & 10 & 7 & 10 & 10 & 4 \\
\hline \multirow[t]{3}{*}{$\mathrm{mb} \mathrm{L}$} & Mean & 2.42 & 1.49 & 0.95 & 0.52 & 0.89 & 0.91 & 0.60 \\
\hline & SD & 0.06 & 0.04 & 0.04 & 0.03 & 0.02 & 0.03 & 0.08 \\
\hline & Number & 10 & 10 & 10 & 2 & 10 & 10 & 2 \\
\hline \multirow[t]{3}{*}{$\mathrm{mb} R$} & Mean & 2.40 & 1.48 & 0.94 & 0.51 & 0.90 & 0.92 & 0.63 \\
\hline & SD & 0.05 & 0.03 & 0.04 & 0.08 & 0.03 & 0.02 & 0.03 \\
\hline & Number & 10 & 10 & 10 & 2 & 10 & 10 & 2 \\
\hline
\end{tabular}

\begin{tabular}{|c|c|c|c|c|c|c|c|c|}
\hline \multirow{2}{*}{\multicolumn{2}{|c|}{$\begin{array}{c}q \% \text { WT } \\
(+1+,+/ 0)\end{array}$}} & \multicolumn{4}{|c|}{ length $(\mathrm{mm})$} & \multicolumn{3}{|c|}{ width (mm) } \\
\hline & & \multirow{2}{*}{$\begin{array}{r}1+2 \\
2.71 \\
\end{array}$} & 1 & \multirow{2}{*}{$\begin{array}{r}2 \\
1.13\end{array}$} & \multirow{2}{*}{$\begin{array}{r}3 \\
0.63\end{array}$} & \multirow{2}{*}{$\frac{1}{1.12}$} & \multirow{2}{*}{$\frac{2}{0.95}$} & \multirow{2}{*}{$\begin{array}{r}3 \\
0.63 \\
\end{array}$} \\
\hline $\mathrm{mx} \mathrm{L}$ & Mean & & 1.78 & & & & & \\
\hline & SD & 0.09 & 0.06 & 0.02 & 0.03 & 0.03 & 0.04 & 0.03 \\
\hline & Number & 10 & 10 & 10 & 2 & 10 & 10 & 2 \\
\hline \multirow[t]{3}{*}{$\mathrm{mx} \mathrm{R}$} & Mean & 2.68 & 1.78 & 1.14 & 0.66 & 1.10 & 0.97 & 0.62 \\
\hline & SD & 0.08 & 0.05 & 0.04 & 0.03 & 0.03 & 0.03 & 0.05 \\
\hline & Number & 10 & 10 & 10 & 2 & 10 & 10 & 2 \\
\hline \multirow[t]{3}{*}{$\mathrm{mb} \mathrm{L}$} & Mean & 2.42 & 1.47 & 0.94 & - & 0.90 & 0.92 & - \\
\hline & SD & 0.06 & 0.04 & 0.04 & - & 0.03 & 0.03 & - \\
\hline & Number & 10 & 10 & 10 & 0 & 10 & 10 & 0 \\
\hline \multirow[t]{3}{*}{$\mathrm{mb} R$} & Mean & 2.42 & 1.48 & 0.94 & 0.66 & 0.88 & 0.90 & 0.73 \\
\hline & $\mathrm{SD}$ & 0.06 & 0.04 & 0.04 & - & 0.03 & 0.04 & - \\
\hline & Number & 10 & 10 & 10 & 1 & 10 & 10 & 1 \\
\hline
\end{tabular}

$\mathrm{mm}$ - millimeters, $\mathrm{SD}$ - standard deviation, $\mathrm{mx}$ - maxilla, $\mathrm{md}$ - mandible, $\mathrm{L}$ - left side, $\mathrm{R}$ - right side, $\bar{\delta} \delta$ - males, $q \mathcal{q}$-females

$1,2,3$ - the first, second and third molar, respectively 
Cheek teeth

Tooth number

In all ICR, WT and Taheterozygous mice, the molar teeth could be identified on the basis of morphological criteria (Gaunt 1955), (Plate I.-III., Fig. 1). In ICR mice, eruption of the third molar into the oral cavity was observed in $80 \%$ of upper quadrants in males or females, and in $70 \%$ and $80 \%$ of lower quadrants in males and females, respectively. In WT mice, the third molar was exposed to the oral cavity in $55 \%$ of male and in $45 \%$ of female upper quadrants, and in $40 \%$ and $35 \%$ of lower quadrants in males and females, respectively. In the Ta-heterozygous females, the third molar could be detected in the oral cavity aspect in $90 \%$ of upper and $75 \%$ of lower dental quadrants.

Three upper molars could be detected in all Ta-homozygous and Ta-hemizygous specimens. The mandibular cheek teeth were identified there as the first, second and third in the mesio-distal sequence. Three teeth were found in the cheek region in $60 \%$ of mandibles (Plate II., Fig. 1F), but only 2 teeth occurred in the other specimens.

The presence of one or four cheek teeth was not observed.

\section{Tooth shape}

a) ICR and WT mice

In phenotypically normal ICR and WT mice, variation in tooth morphology was observed: An extra cusp was present near the base of cusp 1 of the upper M1 in $25 \%$ of teeth in ICR males or females and in $10 \%$ of teeth in WT females. The tips (enamel free areas) of B3 and 3 in the upper M1 were connected in $70 \%$ of male and $50 \%$ of female teeth in ICR stock (Plate I., Fig. 1A), and in $30 \%$ of teeth in WT males or females. The small extra cusp between 
$\mathrm{L} 1$ and B1 appeared in 10\% and $20 \%$ of the lower first molars in I CR males and females, respectively (Plate II., Fig. 1D).

The small cusp B1 of the second upper or lower molar was variable in size in phenotypically normal mice ICR and WT. The B1 cusp was absent in $20 \%$ and $5 \%$ of the second upper molars in WT males and females, respectively. The, rampart "of the upper $\mathrm{M} 2$ was well formed or at least suggested in $65 \%$ and $40 \%$ of teeth in ICR males and females, respectively (Plate I.,Fig. 1A), and in 15\% of male and $10 \%$ of female teeth in WT mice.
Table 4

Mean length and width of the cheek teeth in maxilla and mandible of Ta (tabby) heterozygous females

\begin{tabular}{|c|c|c|c|c|c|c|c|c|}
\hline \multirow{2}{*}{\multicolumn{2}{|c|}{$\subsetneq \subsetneq \mathrm{Ta}(\mathrm{Ta} /+)$}} & \multicolumn{4}{|c|}{ length $(\mathrm{mm})$} & \multicolumn{3}{|c|}{ width (mm) } \\
\hline & & \multirow{2}{*}{$\frac{1+2}{2.59}$} & \multirow{2}{*}{$\frac{1}{1.67}$} & \multirow{2}{*}{$\frac{2}{1.10}$} & \multirow{2}{*}{$\frac{3}{0.60}$} & \multirow{2}{*}{$\frac{1}{1.11}$} & \multirow{2}{*}{$\frac{2}{0.97}$} & \multirow{2}{*}{$\frac{3}{0.68}$} \\
\hline$m x L$ & Mean & & & & & & & \\
\hline & SD & 0.20 & 0.19 & 0.05 & 0.06 & 0.05 & 0.04 & 0.03 \\
\hline & Number & 10 & 10 & 10 & 8 & 10 & 10 & 8 \\
\hline \multirow[t]{3}{*}{$\mathrm{mxR}$} & Mean & 2.63 & 1.70 & 1.07 & 0.63 & 1.08 & 0.95 & 0.64 \\
\hline & SD & 0.19 & 0.21 & 0.05 & 0.13 & 0.05 & 0.07 & 0.07 \\
\hline & Number & 10 & 10 & 10 & 8 & 10 & 10 & 8 \\
\hline \multirow[t]{3}{*}{$\mathrm{mb} \mathrm{L}$} & Mean & 2.44 & 1.55 & 0.89 & 0.55 & 0.89 & 0.89 & 0.55 \\
\hline & SD & 0.08 & 0.03 & 0.05 & 0.04 & 0.03 & 0.05 & 0.04 \\
\hline & Number & 10 & 10 & 10 & 4 & 10 & 10 & 4 \\
\hline \multirow[t]{3}{*}{$\mathrm{mb} R$} & Mean & 2.42 & 1.50 & 0.89 & 0.57 & 0.90 & 0.90 & 0.59 \\
\hline & SD & 0.22 & 0.14 & 0.06 & 0.05 & 0.03 & 0.06 & 0.07 \\
\hline & Number & 10 & 10 & 10 & 4 & 10 & 10 & 4 \\
\hline
\end{tabular}

$\mathrm{mm}$ - millimeters, SD - standard deviation, $\mathrm{mx}$ - maxilla. $\mathrm{md}$ - mandible. $\mathrm{L}$ - left side. $\mathrm{R}$ - right side, $\delta \delta^{\circ}$-males, $\$ \uparrow-$ females

$1,2,3$ - the first, second and third molar, respectively

\section{b) Ta-heterozygous mice}

Most Ta-heterozygous females had lower molars similar to the non-mutant mice. Only $30 \%$ of females exhibited a reduction in the B1 cusp of one lower $\mathrm{M} 1$, and in one specimen both B1 and L1 cusps were absent. The B1 cusp of the lower M2 was absent in 20\% and $50 \%$ of the right and left quadrants, respectively. In $20 \%$ of females, the upper first and second molars exhibited reductions in cusps similar to those from Tahomozygous/hemizygous mice (see below), while all cusps were present in remaining cases. The extra cusp emerged between B2 and B3 (Plate III., Fig. 1G,H) or a ridge connected the same two cusps in 50\% of the first upper molar teeth respectively; the tips of cusps 3 and B3 were connected only in 10\% of cases (Fig. 1G). The "rampart" was formed in 35\% of the second upper molars. Otherwise, the B1 and/or B3 cusp was reduced (Fig. 1G) in $50 \%$ or absent in $80 \%$ of the upper second molars.

\section{c) Ta-homozygous/hemizygous mice}

In Ta-homozygous/hemizygous mice, the upper first molars were uniformly affected (Plate I., Fig. 1C): Reduction in the cusp 1, a strong reduction or diminution of $\mathrm{L} 1$ and $\mathrm{B} 1$, and an absence of B3. In the place of the former cusps 1, L1 and L2, a unit ridge was formed. The cusps B2 and 2 were closer aligned, whilst the interconnection between 2 and L2 was disrupted. In the second upper molar, the B 3 cusp was absent, the interconnection between 2 and L2 was suppressed and the L2 cusp moved distally. A small accessory cusp interposed between L1 and L2 (Fig. 1C) or a ridge interconnecting $\mathrm{L} 1$ with $\mathrm{L} 2$ was found in most cases. The "rampart" (Fig. 1C) was present in $60 \%$ of teeth. In the lower jaw, two or three teeth were present (Plate II., Fig. 1F). The most mesially situated tooth exhibited variable shape showing one or more cusps on its occlusal surface. The occlusal surface of the second tooth was regularly formed by two transversal ridges, suggesting a fusion of $\mathrm{B} 2+\mathrm{L} 2$ and $\mathrm{B} 3+\mathrm{L} 3$ cusps. The third, most distally locate $\mathrm{d}$ tooth (when present) possessed a transversal row of two cusps mesially (or a ridge suggesting a fusion between them); at its distal end, a single cusp or a transverse ridge was apparent (Plate II., Fig. 1F). 
Upper jaw

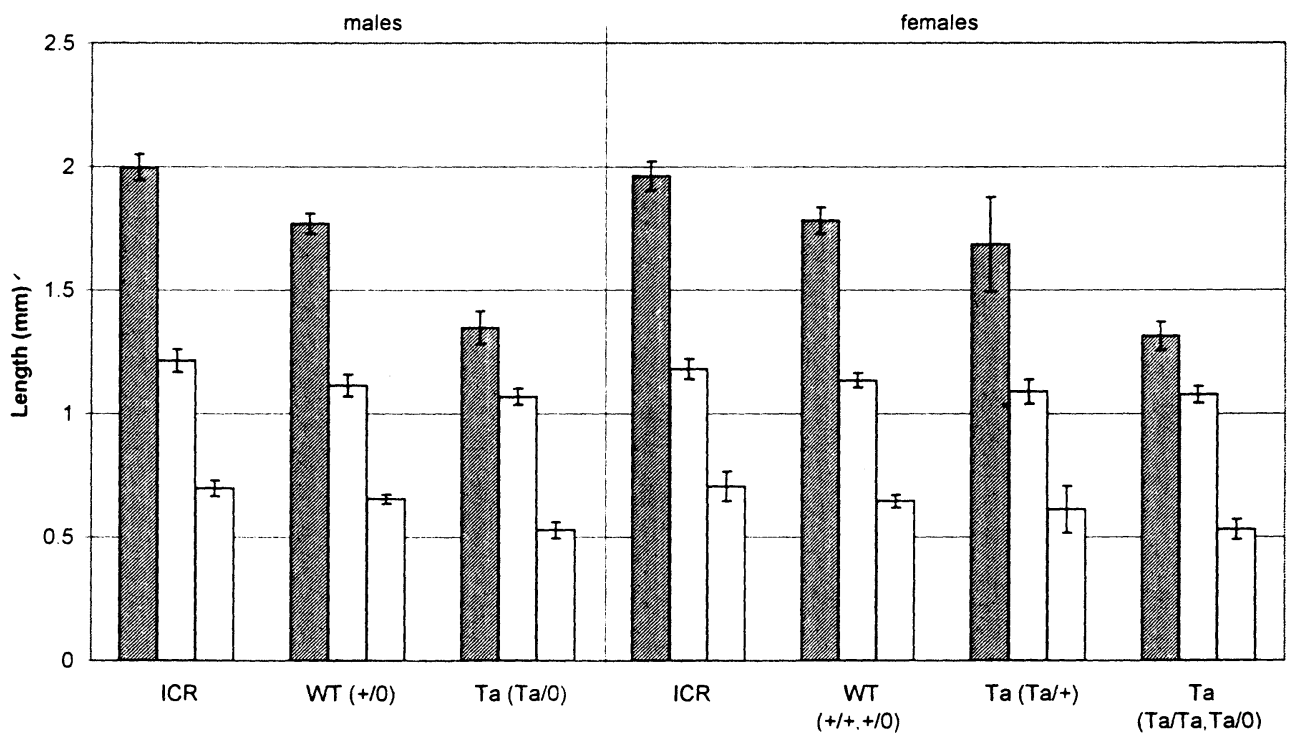

Upper jaw

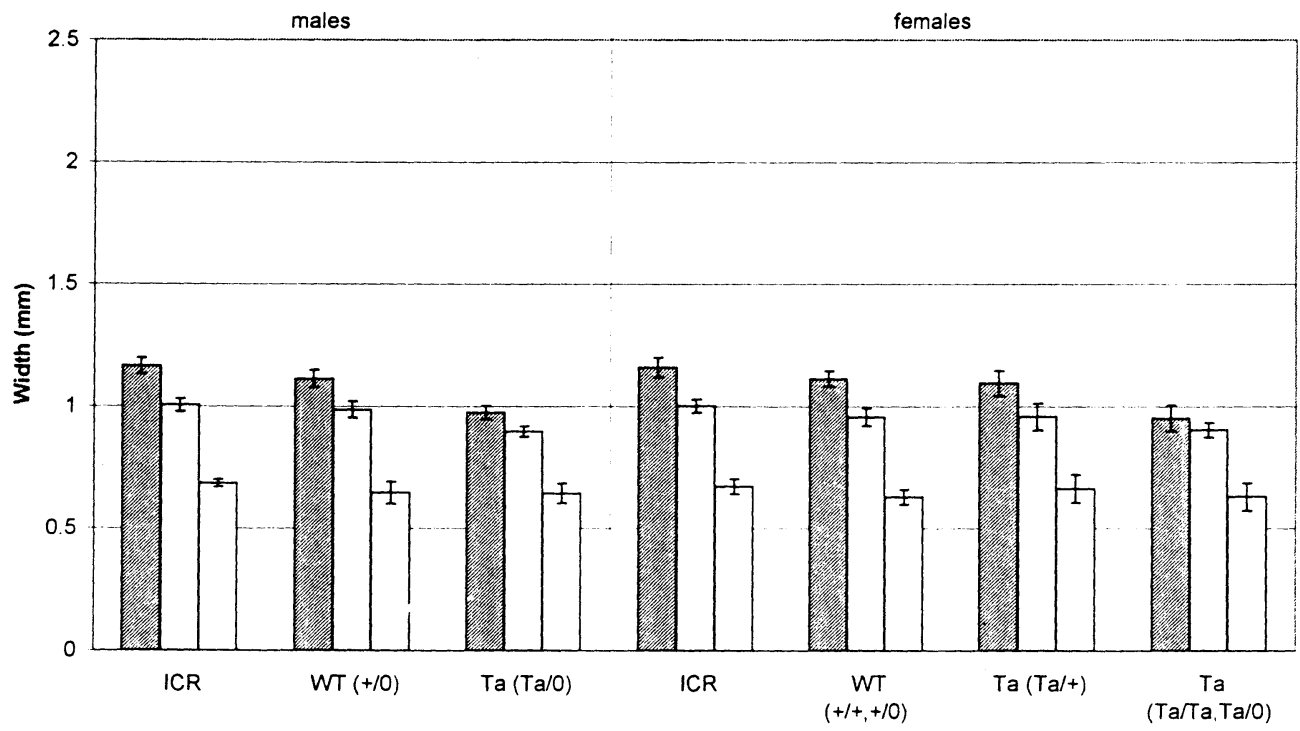

Fig. 2. Mean length and width of the upper cheek teeth of males and females in ICR and in different phenotype/genotype subgroups of WT (wild type) and Ta (tabby) mice. The dark, grey or white column represents mean value for the respective first, second or third molars (right + left). Bar - standard deviation, mm - millimeters.

\section{Tooth size}

a) Right/left side differences

The rightleft differences were found only for several parameters in the non-mutant WT or ICR 
mice: Compared to the left side, the right sided upper $\mathrm{M} 1$ was longer and more narrow $(\mathrm{P}<0.05)$ in WT males; the lower $\mathrm{M} 1$ and $\mathrm{M} 2$ were narrower $(\mathrm{P}<0.05$ and 0.01 , respectively) in WT females; the upper M1 was longer and the lower M2 was wider $(\mathrm{P}<0.05)$ in ICR males; the lower M1 was

\section{Lower jaw}

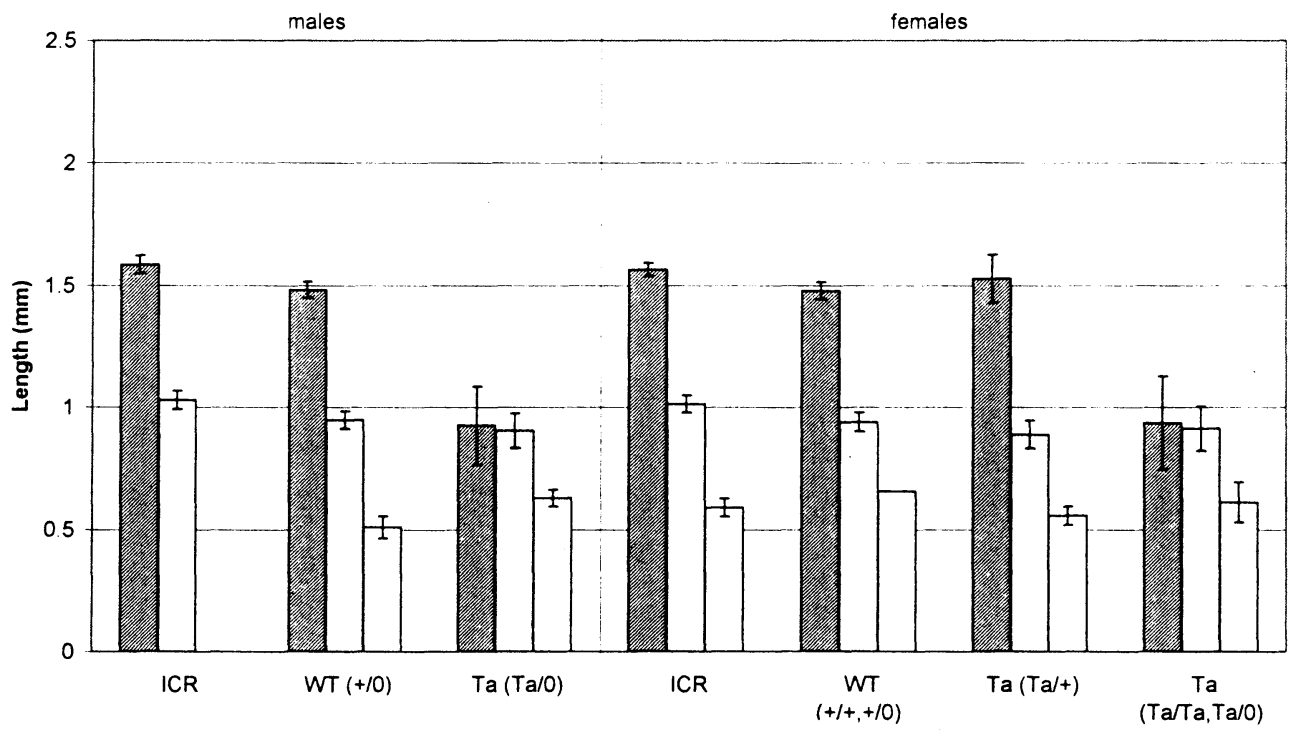

Lower jaw

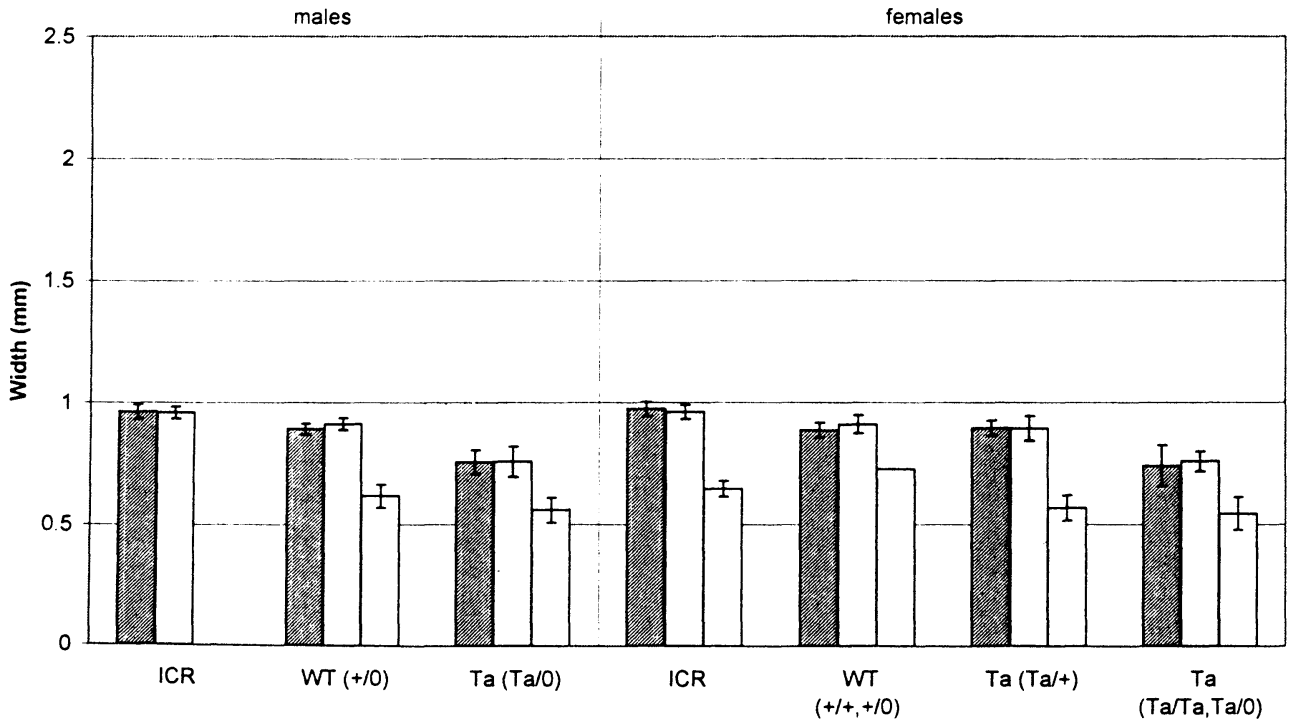

Fig. 3. Mean length and width of the lower cheek teeth of males and females in ICR and in different phenotype/genotype subgroups of WT (wild type) and Ta (tabby) mice. The dark, grey or white column represent mean value for the first, second or third molars (right + left), respectively (in ICR, WT and Ta-heterozygous mice), or for the first, second and third cheek teeth (right + left), respectively (in Ta-homozygous/hemizygous mice). Bar - standard deviation, mm - millimeters. 
shorter $(\mathrm{P}<0.05)$ and the upper $\mathrm{Ml}$ was narrower $(\mathrm{P}<0.05)$ in ICR females. No significant differences were observed in Ta-mice.

\section{b) Sex differences}

In comparison with corresponding females, the ICR males exhibited longer upper M2 teeth $(\mathrm{P}<0.05)$ and a larger total length for $\mathrm{M} 1+\mathrm{M} 2$ teeth in both the upper and lower jaws $(\mathrm{P}<0.01)$; a wider upper M2 tooth $(\mathrm{P}<0.05)$ was found in WT males. We found no differences in tooth sizes between tabby males and females (Tab. 1-4, Fig. 2 and 3).

\section{c) ICR and WT mice}

The tooth dimensions were significantly smaller $(\mathrm{P}<0.01)$ in WT specimens than in the ICR strain, except for a less significant difference $(\mathrm{P}<0.05)$ in the width of the left upper $\mathrm{M} 1$ in males and M2 in females. The width of the upper M2 in males did not differ (Tab. 1 and 2, Fig. 2 and 3).

d) Various phenotypes of the tabby mice

When compared to the WT males, the Ta-hemizygous males possessed significantly smaller teeth: the lower second cheek tooth was shorter $(\mathrm{P}<0.05)$ and all remaining parameters were smaller $(\mathrm{P}<0.01)$. Similarly, all tooth parameters were significantly smaller $(\mathrm{P}<0.01)$ in Ta-homozygous/hemizygous than in WT females except for the length of the lower second cheek tooth. In contrast, the Ta-heterozygous females did not differ from the WT females except for the shorter upper M1 $(\mathrm{P}<0.05)$ and shorter upper and lower M2 $(\mathrm{P}<0.01$ ), (Tab. 2-4, Fig. 2 and 3).

All morphometric parameters were significantly smaller $(\mathrm{P}<0.01)$ in teeth from the Tahomozygous/hemizygous than from Ta-heterozygous females, except for the length of the upper M2 and the lower second cheek tooth (Tab. 3 and 4, Fig. 2 and 3).

In the lower quadrants, the most mesially situated cheek tooth was longer than its distal neighbour in $50 \%$ of Ta-hemizygous males and in $45 \%$ of Ta-homozygous/hemizygous females.

e) The same phenotype offsprings of phenotypically different mothers

Two samples of Ta-homozygous/hemizygous females were ranked according to their Ta-heterozygous or Ta-homozygous/hemizygous mothers. Analysis of the tooth size in these two samples showed a difference related only to the width of the lower M2 $(\mathrm{P}<0.05)$ : teeth were wider in daughters of Ta-heterozygous mothers.

\section{Body weight}

The mean body weight of the ICR males or females ( $19.2 \mathrm{~g}$ or $16.7 \mathrm{~g}$, respectively) was two times higher than in all remaining groups of the inbred mice. Among the inbred mice, there was no significant difference in weight between either the WT males and Ta-hemizygous males $(9.73 \mathrm{~g}$ and $8.04 \mathrm{~g}$, respectively), or between WT females and Ta-homozygous/hemizygous females ( $8.53 \mathrm{~g}$ and $7.59 \mathrm{~g}$, respectively). The only significantly higher body weight was found in Ta-heterozygous females $(11.4 \mathrm{~g})$, when compared to ei ther Tahomozygous/hemizygous females (7.59 g) - $\mathrm{P}<0.01$, or WT females (8.53 g) - $\mathrm{P}<0.05$.

\section{Discussion}

In contrast to the $\mathrm{X} / \mathrm{O}$ condition in humans (Turner's syndrome), the $\mathrm{X} / \mathrm{O}$ mice are anatomically normal and fertile (A shworth et al. 1991; Omoe and Endo 1994). For this reason both $\mathrm{X} / \mathrm{X}$ and $\mathrm{X} / \mathrm{O}$ mice could be used in breeding and their offspring collected in the tabby as well as in non-tabby (wild type) groups. 
In the present study, a parallel evaluation of tooth morphology and size was performed in a common random-bred laboratory mouse - ICR stock which has been used for a recent revision of tooth morphogenesis in normal mouse embryos (Lesot et al. 1996; Peterková et al. 1996; Turečková et al. 1996; Viriot et al. 1997). It is known that non-inbred mice are generally more robust than mice of an inbred strain (Green 1981b). Indeed, the body weight was two times higher in the random-bred ICR mice than in all the remaining groups of inbred animals (WT, Ta-homozygous/hemizygous, Taheterozygous). The bigger size of the whole body can explain the existence of significantly larger (although morphologically similar) teeth in the ICR strain, when compared to those in non-mutant (WT) controls of the tabby mice.

The anomalies in the dentition of the tabby mice and some aspects of their tooth development have been described previously by Grüneberg (1965, 1966), Sofaer (1969ab, 1975, 1979) and Miller (1978). Miller (1978) found a higher frequency of incisor anomalies in the upper jaw in Ta-hemizygous males, whilst Sofaer (1969) reported the lower jaw to be more affected. We found nearly the same frequency of missing incisors in both jaws in Ta-hemizygous males, with a predominance on the right side; the Ta-homozygous/hemizygous females were less affected, and predominantly in the lower jaw. These differences can be explained by the fact that expression of a phenotypic feature is influenced by the genetic background on which a mutant gene finds itself. The stock backgrounds differ in their ability to favour the appearance of tooth variability, or anomaly induced by a mutant gene (Grüneberg 1965; S of a er 1969bc, 1979; Sofaer and MacLean 1970). In the present study, the stock of the tabby mice B6CBACa-AW-J/A-Ta/0 was used. The genetic background of mice carrying the Ta gene was heterogenous in Grüneberg' s study (Grüneberg 1966); the strains A and/or JU were employed by Sofaer $(1969 b, 1975,1979)$ and the strain C3Hf was used by Miller (1978).

The findings reported here illustrate a decrease in the crown size and reduction or even disappearance of cusps in the cheek teeth of Ta-homozygous/hemizygous animals. These results are in agreement with earlier data (Grüneberg 1966; Sofaer 1969b; Miller 1978). In contrast to S of aer (1969b), however, the pattern of tabby dental affection was not well maintained in the present Ta-heterozygotes. Besides shape parameters, Sofaer $(1975,1979)$ also evaluated the maximum mesio-distal length in all cheek teeth in the Taheterozygous females and the length of the first molars in control males. Compared to the present Ta-heterozygous females, Sofaer (1979) reported conspicuously shorter upper M1, M2 and lower M1 teeth in heterozygotes, while the length of the first molars in male controls (S of a er 1975) was similar to our control data. A frequent difference in the present Ta-heterozygotes from their wild-type controls was the extra cusp interposed in the former group between B2 and B3, or the ridge connecting B2 with B3 cusps of the first upper molar. Grüneberg (1966) considered these features as common minor variants not specifically related to the tabby. Both the extra cusp and the ridge have been described as variations regularly present in A and BALB/c strains of mice, respectively (Grüneberg 1965). A question remains, however, as to why the manifestation of this feature was favoured in the heterozygous specimens? Although the "rampart" of the upper M2 situated in front of cusp 2 (Grüneberg 1966) has been considered to be a specific feature of the tabby dentition (Grüneberg 1966; S ofaer 1969ab; Miller 1978), this structure was also found in non-tabby wild type (WT) mice and it was frequently present in ICR specimens.

We failed to find in the present collection a macrodontia in place of the first molar, or four cheek teeth explicitly documenting the existence of a supernumerary tooth in front of the 
molars. The identification of a supernumerary tooth in tabby mice is complicated in case of problems with identification of the molars themselves - because they are conspicuously reduced in size, show changes in the cusp pattern and exhibit a putative absence of the third molar. So faer (1969b) assumed as supernumerary the most mesial cheek tooth, whose size is smaller than the size of the tooth adjacent distally. The author himself, however, did not consider this criterion to be ideal (Sofaer 1969b). According to such a criterion, a "supernumerary" tooth was present in about one half of the lower jaw quadrants in our Tahomozygous/hemizygous specimens. Prenatal studies should help to elucidate not only the problem of identification of the supernumerary tooth, but also mechanisms involved in the aetiopathogenesis of other dental abnormalities in the tabby mice.

\section{Porovnání tvaru a velikosti zubů u tabby a non-tabby myší}

Základní anatomická a embryologická pozorování zubních poruch u tabby myší byla provedena před 20-30 lety. Charakteristiky tabby dentice musely být proto revidovány u kmene dostupného v současné době, $s$ cílem překlenout mezeru ve výzkumných aktivitách na tomto poli a vytvořit předpoklady pro budoucí vývojové studie. Stanovili jsme kvalitativní a kvantitativní parametry funkčních zubů u samců i u samic různých fenotypů získaných $\mathrm{z}$ kmene tabby myší. Souběžná studie byla provedena také u myší běžného laboratorního kmene ICR. Tělesná váha ICR myší byla dvojnásobná oproti nemutantním kontrolám tabby myší. V souhlase s vy̌ší váhou jsme u myší kmene ICR nalezli také větší zuby, které se však tvarově nelišily od tabby nemutantních kontrol. U tabby homozygotních a hemizygotních myší chyběl alespoň jeden řezák u 50\% samic a 70\% samcủ, kde byla také výrazná převaha výskytu této vady na pravé straně. U těchto skupin byla významně zmenšena průměrná délka i šířka tvářových zubů ve srovnání s odpovídající kontrolou, přestože tělesná váha se významně nelišila. Charakteristický tvar tvářových zubů byl výsledkem změn $v$ uspořádání korunky, které zahrnovaly také zmenšení nebo chybění hrbolků. Na rozdíl od dřívějších literárních údajů jsme $\mathrm{v}$ našem souboru tabby myší nenalezli zdvojené řezáky ani jednoznačně prokazatelný nadpočetný tvářový zub a heterozygotní jedinci vykazovali menší poškození zubů.

\section{Acknowledgements}

The authors thank to Dr. A. J. Smith for critical reading of the manuscript. This work was supported by the Grant Agency of the Academy of Sciences of the Czech Republic (grant A7039503) and by Ministry of Education, Youth and Sports of the Czech Republic (COST B8.10).

\section{References}

ASHWORTH, A., RASTAN, S., LOWELL-BADGE, R., KAY, G. 1991: X-chromosome inactivation may explain the difference in viability of XO humans and mice. Nature 351 (6325): 406-408

BLECHER. S. R. 1986: Anhidrosis and absence of sweat glands in mice hemizygous for the Tabby gene: supportive evidence for the hypothesis of homology between Tabby and human anhidrotic (hypohidrotic) ectodermal dysplasia (Christ-Siemens-Touraine syndrome). J. Invest. Dermatol. 87: 720-722

COHN, S. A. 1957: Development of the molar teeth in the albino mouse. Am. J. Anat. 101: 295-320

CRAWFORD, P. J. M., ALDRED, M. J., CLARKE, A. 1991: Clinical and radiographic dental findings in X-linked hypohidrotic ectodermal dysplasia. J. Med. Genet. 28: 181-185

GAUNT, W. A. 1955: The development of the molar pattern of the mouse (Mus musculus). Acta Anat. 24: 249-268

GREEN, M. C. (Ed.) $1981 \mathrm{a}$ : Genetic Variants and Strains of the Laboratory Mouse. Gustav Fischer Verlag, Stuttgart, New York, $476 \mathrm{p}$.

GREEN, E. L. 1981b: Breeding systems. In: The Mouse in Biomedical Research I. (Eds. H. L. FOSTER, J. D. SMALL, J. G. FOX). Academic Press, London, pp. 91-104 
GRÜNEBERG, H. 1965: Genes and genotypes affecting the teeth of the mouse. J. Embryol. exp. Morph. 14: 137-159

GRUNEBERG, H. 1966: The molars of the tabby mouse, and a test for the single-active X-chromosome hypothesis. J. Embryol. exp. Morph. 15: 223-244

GRÜNEBERG, H. 1971: The tabby syndrome in the mouse. Proc. R. Soc. Lond. B. 179: 139-156

JORGENSON, R. J. 1980: Clinician's view of hypodontia. J. Am. Dent. Ass. 101: 283-286

LESOT, H., VONESCH, J. L., PETERKA, M., TURECKOVÁ, J., PETERKOVÁ. R., RUCH. J. V. 1996: Mouse molar morphogenesis revisited by three dimensional reconstruction: II. Spatial distribution of mitoses and apoptosis in cap to bell staged first and second upper molar teeth. Int. J. Dev. Biol. 40: 1017-1031

MILLER, W. A. 1978: The Dentitions of Tabby and Crinkled Mice (an upset in mesodermal:ectodermal interaction). In: Development, Function and Evolution of Teeth (Eds. P.M. BUTLER and K.A. JOYSEY), pp. 99-109. Academic Press, London

OMOE, K., ENDO, A. 1994: Expression level of Rps4 mRNA in 39,X mice and 40,XX mice. Cytogenet. Cell. Genet. 67: $52-54$

PETERKOVÁ, R., LESOT, H., VONESCH. J. L., PETERKA, M., RUCH, J. V. 1996: Mouse molar morphogenesis revisited by three-dimensional reconstruction: $I$. Analysis of initial stages of the first upper molar development revealed two transient buds. Int. J. Dev. Biol. 40: 1009-1016

PÖYRY, M., RANTA, R. 1985: Anomalies in the deciduous dentition outside the cleft region in children with oral cleft. Proc. Finn. Dent. Soc. 81: 91-97

RAVN. J. J. 1971: Aplasia, supernumerary teeth and fused teeth in primary dentition. Scand. J. Dent. Res. 79: 1-6

SALMON, M. A., LINDENBAUM, R. H. 1978: Developmental Defects and Syndromes. HM+M Publishers Ltd, Aylesbury, England, $432 \mathrm{p}$.

SOFAER, J. A. 1969a: Aspects of the tabby-crinkled-downless syndrome. I. The development of tabby teeth. J. Embryol. exp. Morph. 22: 181-205

SOFAER, J. A. 1969b: Aspects of the tabby-crinkled-downless syndrome. II. Observations on the reaction to changes of genetic background. J. Embryol. exp. Morph. 22: 207-227

SOFAER, J. A. 1969c: The genetics and expression of a dental morphological variant in the mouse. Archs Oral Biol. 14: 1213-1223

SOFAER, J. A. 1975: Interaction between tooth germs and the adjacent dental lamina in the mouse. Archs Oral Biol. 20: $57-61$

SOFAER, J. A. 1979: Additive effects of the genes tabby and crinkled on tooth size in the mouse. Genet. Res. Camb. 33: $169-174$

SOFAER, J. A., MacLEAN, C. J. 1970: Dominance in threshold characters. A comparison of two tabby alleles in the mouse. J. Genetics 64: 273-280

TUREĆKOVÁ, J., LESOT, H., VONESCH, J. L., PETERKA, M., PETERKOVÁ, R., RUCH, J. V. 1996: Apoptosis is involved in disappearance of the diastemal dental primordia in mouse embry'o. Int. J. Dev. Biol. 40: 483-489

VIRIOT, L., PETERKOVA, R., VONESCH, J. L., PETERKA, M., RUCH, J. V., LESOT, H. 1997: Mouse molar morphogenesis revisited by three dimensional reconstruction: III. Spatial distribution of mitoses and apoptoses up to bell-staged first lower molar teeth. Int. J. Dev. Biol. 41: 679-690

WEEKS, N. L. 1983: Evidence from thiol histochemistry for homology between the Tabby-crinkled syndrome in mice and human ectodermal dysplasia. J. Histochem. Cytochem. 311: 1407-1411 
Plate I.

Čermáková P. et al.: Comparison... pp. 3-12
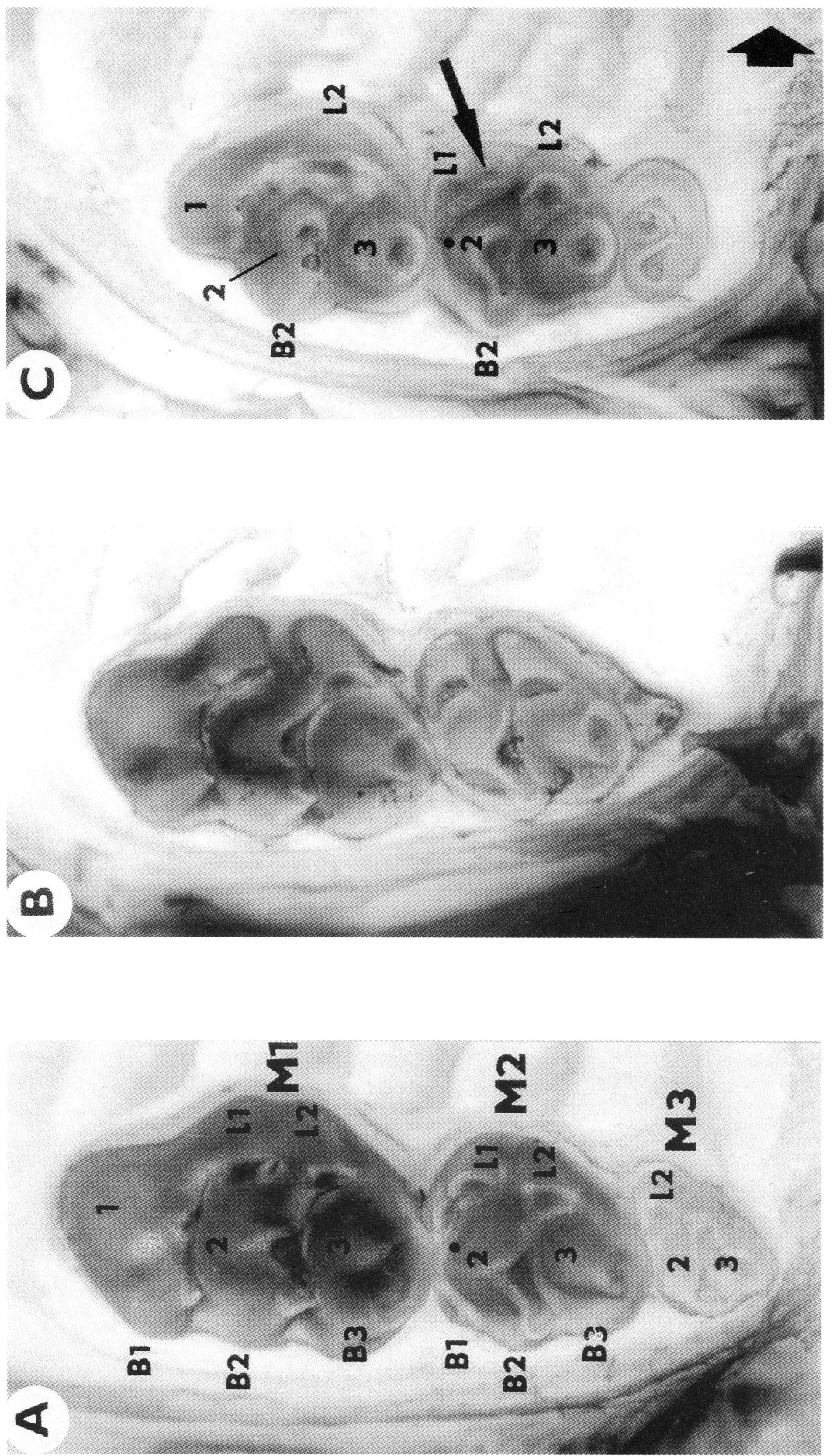
Plate II.
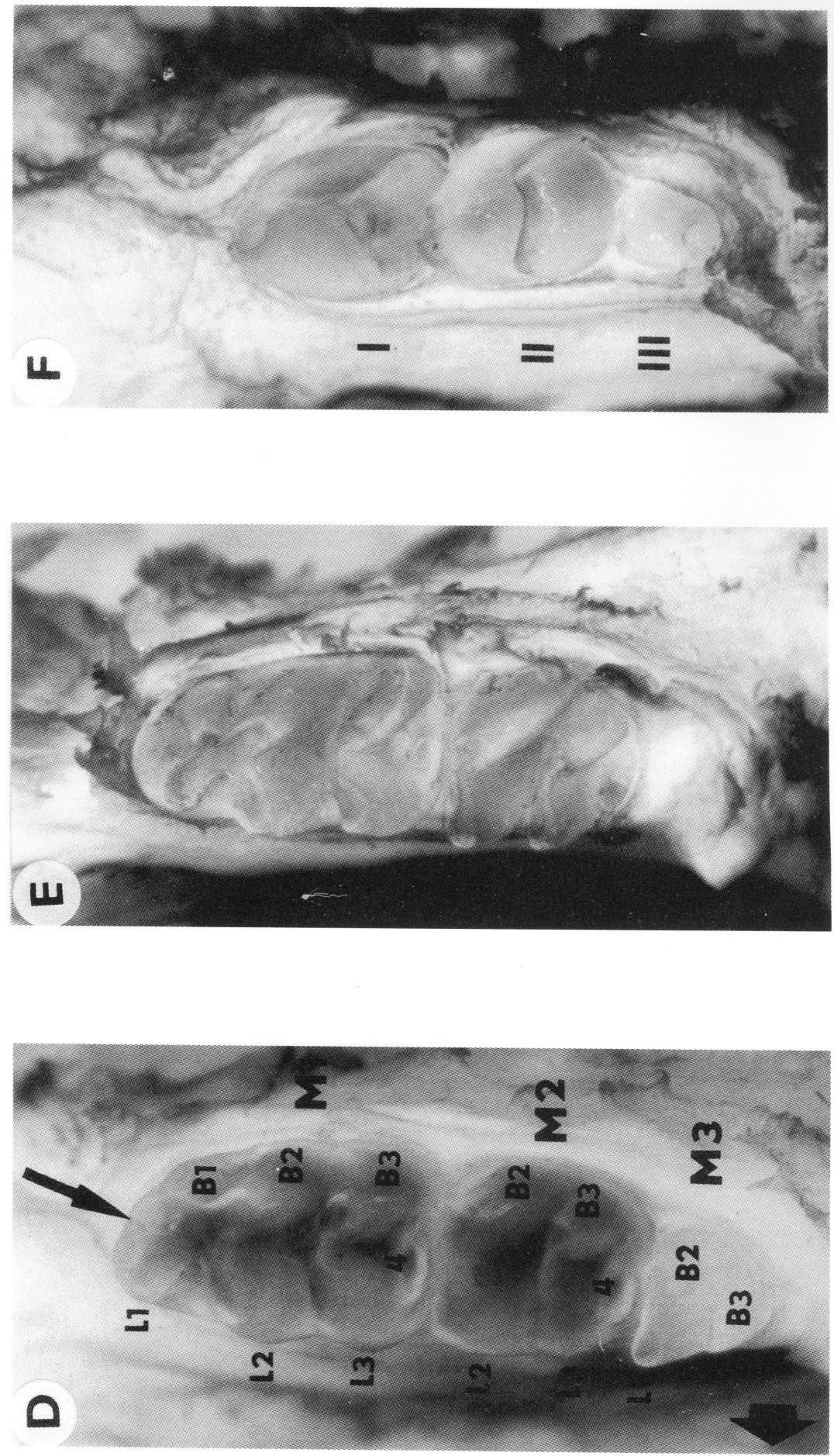


\section{Plate III.}
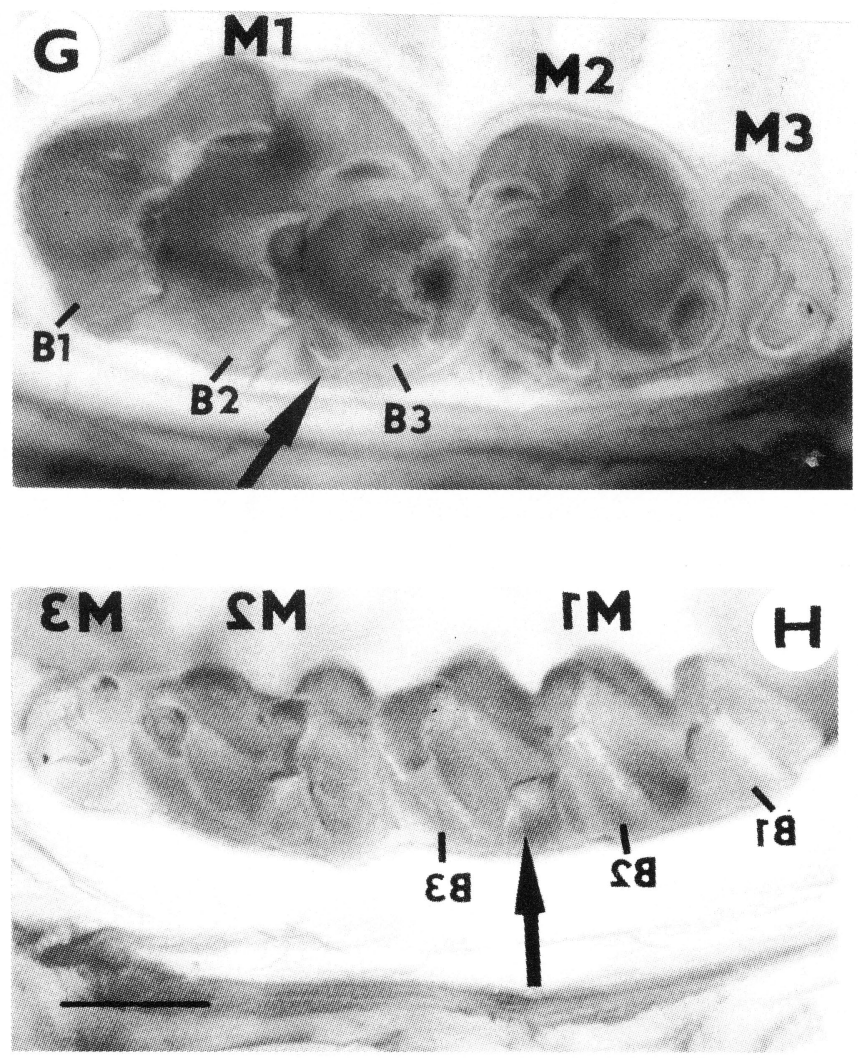

Fig. 1. Cheek teeth in the upper $(A, B, C, G, H)$ and lower $(D, E, F)$ jaw in ICR (A,D), wild type (B,E), Ta-homozygous/hemizygous (C,F) and Taheterozygous $(\mathrm{G}, \mathrm{H})$ females. The teeth are presented in occlusal $(\mathrm{A}-\mathrm{G})$ or in buccal $(\mathrm{H})$ views. M1, M2, M3 - respectively refer to the first, second and third molar (if present), except for the Ta-homo/hemizygous lower jaw (F), where the teeth were indicated as I, II, III in the mesiodistal sequence. The buccal (B1-B3), lingual (L1-L3) and middle (1-4) cusps are indicated. The slim arrow points to the extra cusp situated between L1 and L2 of the upper M2 in Ta-homozygous/hemizygous mouse (C), between L1 and B1 of the lower M1 in the ICR mouse (D) and between B2 and B3 of the upper M1 in the Ta-heterozygous mouse $(\mathrm{G}, \mathrm{H})$. The black dot $(\mathrm{A}, \mathrm{C})$ indicates the furrow separating the "rampart" (Grüneberg 1966) from the cusp 2 in the second upper molar. An extra cusp present buccaly to L1 seemed to contribute to the "rampart" formation (A). The large arrow points lingually. Bar - $0.5 \mathrm{~mm}$. 